\title{
The Role of the Corporation in Society: An Alternative View and Opportunities for Future Research
}

\section{Citation}

Serafeim, George. "The Role of the Corporation in Society: An Alternative View and Opportunities for Future Research." Harvard Business School Working Paper, No. 14-110, May 2014.

\section{Permanent link}

http://nrs.harvard.edu/urn-3:HUL.InstRepos:13506440

\section{Terms of Use}

This article was downloaded from Harvard University's DASH repository, and is made available under the terms and conditions applicable to Open Access Policy Articles, as set forth at http:// nrs.harvard.edu/urn-3:HUL.InstRepos:dash.current.terms-of-use\#OAP

\section{Share Your Story}

The Harvard community has made this article openly available.

Please share how this access benefits you. Submit a story.

\section{Accessibility}


H A R VAR D

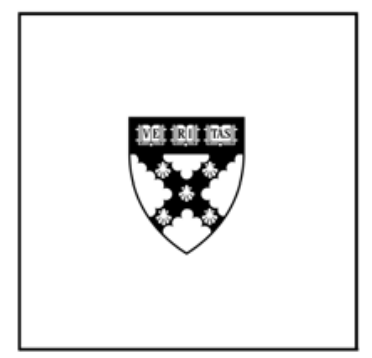

\section{The Role of the Corporation in Society: An Alternative View and Opportunities for Future Research}

George Serafeim

\section{Working Paper}

14-110

May 5, 2014 
The Role of the Corporation in Society:

An Alternative View and Opportunities for Future Research

\author{
George Serafeim*
}

Harvard Business School

\begin{abstract}
A long-standing ideology in business education has been that a corporation is run for the sole interest of its shareholders. I present an alternative view where increasing concentration of economic activity and power in the world's largest corporations, the Global 1000, has opened the way for managers to consider the interests of a broader set of stakeholders rather than only shareholders. Having documented that this alternative view better fits actual corporate conduct, I discuss opportunities for future research. Specifically, I call for research on the materiality of environmental and social issues for the future financial performance of corporations, the design of incentive and control systems to guide strategy execution, corporate reporting, and the role of investors in this new paradigm.
\end{abstract}

\footnotetext{
* George Serafeim is at Harvard Business School. The Division of Faculty Research and Development of the Harvard Business School provided financial support for this project. I am indebted to Robert Eccles without whom I would not have studied many of the phenomena described in this article. I am grateful to Ioannis Ioannou, Joshua Margolis, Tim Youmans, and Rodrigo Verdi and participants at the Information, Organization, and Markets conference at Harvard Business School for many helpful comments. Andrew Knauer provided excellent research assistance. None of these individuals necessarily agree with the conclusions of this paper. All errors are my own. Contact email: gserafeim@hbs.edu.
} 


\section{Introduction}

Corporations are now engaging in environmental and social causes with multiple stakeholders in mind. ${ }^{1}$ I attribute this phenomenon to the increasing concentration of economic activity in the world's largest corporations, which has led to a larger social and environmental impact from the activities of few corporations that can be more easily located and held accountable by an increasingly activist civil society. The depersonalization of property and the objectification of the corporation, associated with the separation of ownership and control, have further contributed to the shifting role of the corporation in society. I describe future opportunities for research arising from an alternative view of the corporation in society, where the world's largest corporations attach greater importance to the interests of stakeholders. ${ }^{2}$

During the last twenty years, an increasing number of companies have voluntarily integrated social and environmental policies in their business model and operations. Similarly a large number of companies have started to externally report their environmental and social performance, in addition to their financial performance. This increased emphasis on the relationship between business and society can be justified based on economic grounds. This is the well-known 'doing well by doing good' theory (Margolis, Elfenbein and Walsh, 2003), whereby improving environmental and social performance will eventually lead to higher levels of financial performance. This claim is based on the belief that meeting the needs of other stakeholders, such as employees through investment in training and customers through superior product quality and safety, directly creates value for shareholders (Freeman et al., 2010, Porter and Kramer, 2011). It is also based on the belief that not meeting the needs of other stakeholders can destroy shareholder value through, for example, consumer boycotts (Sen, Gurhan-Canli and Morwitz 2001), the inability to hire the most talented people (Greening and Turban 2000), and punitive fines by the government (Hillman and Keim, 2001).

On the other hand, scholars have argued that engaging in environmental and social initiatives can destroy shareholder wealth (Friedman 1970; Navarro 1988; Galaskiewicz 1997). In its simplest form the argument states that these initiatives are just another type of agency cost, where managers receive private benefits from embedding environmental and social policies in the company, but doing so has negative financial implications (Baloti and Hanks 1999; Brown, Helland, and Smith 2006). More broadly, according to this argument management might lose focus by diverting attention to issues that are not core to the company's strategy and business model. Moreover, these companies might experience a higher cost structure by, for example, paying their employees above-market wages, engaging in environmental mitigation efforts beyond that required by regulation, failing to reduce their payroll rapidly enough in

\footnotetext{
${ }^{1}$ For example, Southwest Airlines has identified employees as their primary stakeholder; Novo Nordisk has identified patients (i.e., their end customers) as their primary stakeholder; Natura has committed to preserving biodiversity and offering products that have minimal environmental impact.

${ }^{2}$ Stout (2012) argues that the normative argument that the fiduciary duty of managers and directors is to maximize shareholder wealth is not consistent with US corporate law.
} 
times of economic austerity, passing on valuable investment opportunities that are not consistent with their values, earning lower margins on their products due to more expensive sourcing decisions to appease an NGO, and losing customers to competitors by charging a higher price for features that customers are potentially not willing to pay for, such as responsibly and environmentally-friendly sourced raw materials. Companies that do not operate under these constraints will, it is argued, be more competitive and, as a result, thrive better in the competitive environment. The hypothesis that companies trying to address environmental and social issues will underperform is well captured in Jensen (2001): 'Companies that try to do so either will be eliminated by competitors who choose not to be so civic minded, or will survive only by consuming their economic rents in this manner.' (p. 16).

However, as I will argue below, a positive link between environmental and social responsibility and financial performance is not a necessary condition for firms to manage and disclose their environmental and social activities. Nor is it the case that a focus on the environment and society is necessarily a manifestation of an agency problem. To characterize a managerial action as an agency problem, one needs to identify accurately the principal and her/his objectives. I will argue that as economic activity became concentrated in just a handful of corporations, their role in society was shaped to serve broader interests and not just shareholders. As a result society, not just shareholders, also became the principal. Berle and Means (1932) predicted this many decades ago. In their own words 'The control groups have, rather, cleared the way for the claims of a group far wider than either the owners or the control [groups]. They have placed the community in a position to demand that the modern corporation serve not alone the owners or the control but all society.' (p. 312).

The shifting role of the corporation in society is consistent with companies engaging not only with environmental and social issues that are important for their future financial performance, but also with issues that are immaterial for their future financial performance (Eccles and Serafeim, 2013). Companies not only spend resources to improve their environmental and social performance on immaterial issues, but they also report on those efforts. A study by the Sustainability Accounting Standards Board (SASB) found that 50 percent of disclosures related to environmental and social issues are immaterial for the future long-term financial performance of a company. ${ }^{3}$ However, the shifting role of the corporation in society would predict this phenomenon; the Global 1000 will engage in societal issues that are important to a wide range of stakeholders, independent of whether by doing so they will contribute positively to their future profitability. In other words, the Global 1000 strives to improve and report its performance on environmental and social issues that are material to stakeholders, but not the company. The separation of ownership and control means that owners are indifferent about what companies do as long as their capacity to generate returns is not fundamentally impaired. The responsiveness of companies to multiple

\footnotetext{
${ }^{3}$ Ongoing study by the Sustainability Accounting Standards Board (SASB).
} 
stakeholders is aligned with their interests-while it does not promise huge returns, it does protect against precipitous declines.

It is important to highlight that throughout this paper I adopt a positive rather than a normative approach. In other words, I do not discuss whether the increasing concentration of economic activity in the world's largest corporations and the increasingly active management of material and immaterial environmental and social issues is a good or a bad thing. These questions are outside the scope of my paper. However, I discuss findings from the research that examines the relationship between financial and environmental or social performance.

The increasing commitment of corporations to solve environmental and social problems raises a number of fundamental questions for business scholars. First, identifying the most material environmental and social issues for any given company is an area where significant managerial and civil society energy is being devoted, but research is lacking. Second, research on how companies can design their incentive and control systems to drive these environmental and social efforts inside an organization could generate useful insights. Third, we know little about how the disclosure of environmental and social information has changed managerial behavior. A long-standing assumption behind civil society actors, like the Global Reporting Initiative (GRI) and the Carbon Disclosure Project (CDP), is that reporting can drive performance. Fourth, the corporate reporting landscape is being revolutionized by the introduction of integrated reporting. However, we lack any systematic evidence about the benefits and costs of integrated reporting. Nor do we have a clear understanding about how integrated reporting instills 'integrated thinking' inside a firm. Finally, research on how the disclosure of environmental and social data changes resource allocation decisions by investors could shed light on how users of the information force companies to internalize some of their externalities.

The remainder of the paper proceeds as follows. Section 2 describes the increasing concentration of economic activity in the Global 1000 and how the corporate objective shifts as a function of the concentration. Section 3 provides evidence that companies are increasingly engaged in environmental and social issues and that size is an important determinant of this engagement. Finally, section 4 provides a framework with opportunities for future research and section 5 concludes.

\section{The Global 1000}

The large multinational corporations of the $21^{\text {st }}$ century are a relatively new phenomenon. Studying the historical context of the last four centuries clearly illustrates the rise of the large corporation in society and the conditions that allowed for this to happen.

The largest and most influential organizations up through the seventeenth century were the church and the state in Europe. Both the church and the state, two organizations that were often effectively 
merged, threatened by the rise of large corporations, managed to limit corporate power by establishing legal barriers, which restricted corporate growth. This started to change in the $18^{\text {th }}$ century, when projectspecific corporate charters were given to corporations, especially in the U.S. where a weaker federal government allowed state governments to issue corporate charters. However, the ability of organizations to grow was limited due to their project-specific existence, the finite duration of corporate charters, and the difficulty of concentrating large amounts of capital in the then existing legal forms of partnerships and joint-stock companies in the absence of a developed financial system.

This changed in the U.S. when states, beginning with Connecticut in 1837, made incorporation generally available by mere registration; no longer was a special charter from a state legislature needed, and all special charter needs disappeared by 1870 (Perrow 2002). This was preceded by the Supreme Court's infamous 1819 'Dartmouth decision'. With that decision corporations, like people, were given private rights and state control over corporations was made very limited. In the same year, another decision that allowed corporations to grow was the ruling to make owners of corporations not subject to imprisonment for debts, even if as individuals they could be sent to jail for much smaller amounts of debt. The concept of 'limited liability' was born. That same year, a third decision came to further allow corporations to gain power, over employees this time. A ruling declared that the federal government acted for the people directly, and its laws would prevail over the laws of any state in regards to corporate conduct (Sellers 1991). As the federal government barely existed at that point, the economy was left essentially unregulated (Perrow 2002).

Interestingly, as Sellers (1991) documents, this legal revolution was not accidental. At the turn of the $18^{\text {th }}$ century, the lawmakers that instituted these legal changes came from a tiny cohort of elite college graduates. Judges, who did not use to be lawyers before then, now almost exclusively came from this elite group. The law profession grew and became inundated with members of entrepreneurial families who could afford to send their son to law school. Judges assumed more power over legal matters by gradually determining that juries could only rule on matters of fact, not law, and they could not violate the instructions of the judge. Some landmark subsequent decisions tilted the balance of power towards the owners of corporations and away from employees and communities. In 1824, courts announced the doctrine of 'contributory negligence'; the failure to put a guard rail was inconsequential because the employee was negligent in being too close to the machinery when cleaning it. In 1842, it was ruled that if the killed or injured employee was not negligent then it was the fault of his fellow worker but not of the employer; the 'fellow servant' rule. In 1839, externalization of costs from corporate activity was legitimized; a judge in Kentucky ruled that trains could run through Louisville, despite the noise and pollution caused, because so necessary were the 'agents of transportation in a populous and prospering country that private injury and personal damage ... must be expected' (cited in Sellers 1991, page: 52). 
These legal precedents set the stage for the increasing concentration of economic activity in a few large corporations, which was documented in the early $20^{\text {th }}$ century (Berle and Means 1932). This concentration continued throughout the $20^{\text {th }}$ century, assisted by the wave of globalization. As of the end of 2012, just 1,000 corporations (Global 1000) were responsible for half of the total market value of the world's more than 60,000 publicly traded companies. Consider how quickly this situation has emerged. In 1980 the world's largest 1,000 publically listed companies made \$2.64 trillion in revenue, or \$7.0 trillion in 2012 dollars, adjusted using the consumer price index. They directly employed nearly 21 million people, and had a total market capitalization of close to $\$ 900$ billion ( $\$ 2.4$ trillion in 2012 dollars), or 33 percent of the world total. By 2012, the Global 1000 made \$34 trillion in revenue. They directly employed 73 million people, hundreds of millions in their supply chains, and had a total market cap of $\$ 28$ trillion. These companies and their supply chains have an enormous potential to confer both good and ill on society. They create goods and services for customers, wealth for their shareholders, and jobs for millions of people. They also consume vast amounts of natural resources, pollute local and global environment at little or no cost, in the case of large financial institutions they throw economies into recessions due to poor risk management, and, in some cases, hurt employees' well-being if wages and working conditions are inadequate.

This great concentration of economic activity makes clear that the Global 1000 affects billions of people around the world. For example, Philips, the Dutch diversified industrial giant, estimated that it 'improved' the life of 1.7 billion people in 2012 through its products. ${ }^{4}$ Dow estimates that it is consuming, on a daily basis, as much energy as Australia (Eccles et al. 2012). Between 1995 and 2010 efforts to improve Dow's environmental performance resulted in energy savings that could power all residential buildings of California for 20 months (Eccles et al. 2012). Royal Dutch Shell and Wal-Mart booked sales of $\$ 454$ billion and $\$ 447$ billion respectively in 2011. Out of 206 countries recognized by the United Nations, only 26 had nominal Gross Domestic Product (GDP) higher than these sales numbers. Deutsche Bank held $\$ 2.8$ trillion in assets in 2011. Gazprom spent more than $\$ 48$ billion in capital expenditures in 2011 and Toyota more than $\$ 10$ billion in research and development. For comparison, only 16 countries spent more than $\$ 10$ billion in research and development.

The Global 1000 are now able to exercise incredible power over employees, suppliers, customers, and even regulators. Consider for example the extraordinary concentration of food supply in just a handful of multinationals. Nestle, Kellogg's, General Mills, Pepsico, Kraft, Unilever, and Procter \& Gamble comprise a group of consumer goods giants that control the dietary lifestyles of consumers and have been

\footnotetext{
${ }^{4}$ See Philips 2012 Annual Report at http://www.philips.com/shared/assets/Investor_relations/pdf/Annual_Report_English_2012.pdf.
} 
accused of consciously contributing to the increasing problem of obesity. ${ }^{5}$ Or consider that at the end of the first decade of the $21^{\text {st }}$ century, DuPont and Monsanto together dominated the world seed markets for maize $(65 \%)$, and soya (44\%). ${ }^{6}$ Monsanto controlled more than 90 percent of the global genetically modified (GM) seed market. ${ }^{7}$ Three companies, ADM, Cargill, and Zen Noh, handled over 80 percent of U.S. corn exports. ${ }^{8}$ Similarly, through a series of mergers and acquisition in the 1980s, and continuing through today, the U.S. media industry is now dominated by six large conglomerates: Comcast, Walt Disney, News Corp, Time Warner, Viacom, and CBS. ${ }^{9}$ These companies are estimated to control 70 percent of cable broadcasting. Time Warner alone is estimated to transmit news to 178 million unique users every month. ${ }^{10}$

Corporate power is a function of size for several reasons. ${ }^{11}$ First, larger companies are able to affect the political process through lobbying. A long literature documents the effect of lobbying by large corporations on political outcomes (Hillman et al., 2004). Second, larger companies are able to shape consumer preferences through spending large amounts of money on advertising. Third, larger companies are able to exercise more power over employees and establish new labor practices, especially in areas with high unemployment and as a result few outside options for employees. Foxconn, the Chinese manufacturer which has been repeatedly criticized for its labor practices, is still a preferred employer among Chinese workers (Eccles et al., 2011). More generally, large corporations have been shown to shape culture and society by establishing hierarchies and as a result imposing a power structure in society (Perrow, 2002). The hypothesis that size is associated with power is consistent with larger companies having higher profitability margins, such as Return-on-Equity, experiencing slower mean reversion in profitability (Healy et al., 2013), and increasing more their profitability margins by the development of the financial system (Lundholm et al., 2013).

However, the people that the Global 1000 reaches, through its operations and products, have a diverse set of interests in their roles as employees, consumers, investors, and community members. Consumers want high quality products at reasonably low prices. Employees want job security coupled with fair

\footnotetext{
${ }^{5}$ See Michael Moss, February $20^{\text {th }} 2013$, The Extraordinary Science of Addictive Junk Food, The New York Times, http://www.nytimes.com/2013/02/24/magazine/the-extraordinary-science-of-junk-food.html?pagewanted=all\&_r=3\&

${ }^{6}$ ETC Group, 2003, 'Oligopoly, Inc. - concentration in corporate power: 2003', Communiqué, issue 82, NovemberDecember.

${ }^{7}$ ETC Group, 2002, 'Ag biotech countdown: vital statistics and GM crops', update, June.

${ }^{8}$ Memarsadeghi, S \& Patel, R (2003) 'Agricultural restructuring and concentration in the United States: who wins, who loses?' Oakland: Food First.

${ }^{9}$ Alan B. Albarran and Bozena I. Mierzejewska. 2004. "Media Concentration in the U. S. and European Union: A Comparative Analysis.” http://www.cem.ulaval.ca/pdf/albarran_mierzejewska.pdf

${ }^{10}$ Ashley Lutz, June 14, 2012. These 6 Corporations Control 90\% Of The Media In America, Business Insider, http://www.businessinsider.com/these-6-corporations-control-90-of-the-media-in-america-2012-6

${ }^{11}$ Power is defined as the extent to which the behavior of one person or organization is influenced by the behavior of another (Roy, 1997). This definition of power includes both behavioral (e.g. the visible overt behavior of the power wielder in the form of a command, request or suggestion) and structural (e.g. ability to determine the context within which decisions are made by affecting the consequences across alternatives) power.
} 
compensation. Investors want a good return on the money they invested in the company. Local communities want an undisturbed environment and some compensation for giving the company a license to operate in their area. The larger a company the more diverse are the interests of the different stakeholders. For example, a company that produces locally and sells in the same geographic region is likely to find its stakeholders have aligned interests since many of its customers will be part of the local community and also potentially employees. However, in the case of an oil and gas company that extracts oil in Equatorial Guinea and sells downstream in the US the interests of customers, employees, suppliers and local communities are likely to diverge significantly. It should come as no surprise then that as a company becomes larger and exercises more power over individuals with a greatly diverse set of interests, conflict erupts between the individuals that wield the power and those subject to it. As there is a continuous desire for power, there is also a continuous desire to make that power the servant of the individuals affected (Berle and Means 1932).

As we will see in the next section, it is readily observable across the world that, in varying degrees of intensity, civil society is trying to subject corporate activities to a test of public benefit. And with just a few corporations comprising most of the economic activity, it has become easier to locate and hold them accountable for their effects on society. However, the ability to locate a corporate actor is a necessary but not sufficient condition for civil society to increase pressure on corporations, especially given the largely trans-national nature of the Global 1000 corporation. Civil society must also have the resources and capability to exert this pressure. By looking at the data, we can see that national and trans-national nongovernmental organizations (NGOs) representing civil society have grown in power and influence. NGOs in 26 countries account for 31 million employees, or almost 7 percent of the total workforce of those countries. Annually, NGOs in these 26 countries spend about $\$ 1.2$ trillion, almost as much as the largest 1,000 companies of the world spend in capital expenditures. In emerging economies, such as India, Brazil, and the Philippines, where traditionally local NGO presence was weak, more than 200,000 NGOs were registered in $2007 .^{12}$

As a result of their expanded financial and human resources, NGO campaigns against specific corporations or against whole industries are becoming more sophisticated and more effective. These campaigns can have a significant effect on a company by damaging its brand and decreasing its social capital. Many of them have prompted regulatory actions that have affected the cost of doing business, while others have shifted customer attitudes, thereby affecting companies' revenues. At the extreme, they have put the license to operate of companies or even entire industries at risk. ${ }^{13}$

\footnotetext{
${ }^{12}$ Nelson, Jane, "The operation of non-governmental organizations (NGOs) in a world of corporate and other codes of conduct," Corporate Social Responsibility Initiative, working paper No. 34, 2007.

${ }^{13}$ For examples of high profile NGO campaigns against large corporations, such as Royal Dutch Shell, Pfizer, Unocal, and Novartis, see George Serafeim, and Robert Eccles, SMART Firms, 2014.
} 
In addition to large financial and human resources that have increased campaign effectiveness, two other trends have allowed NGO campaigns to become more effective. One is information technologies, such as the internet and social media, which allow fast, low cost, and wide dissemination of information. The ability to quickly and cheaply disseminate information has enabled NGOs to inform people around the world about their campaigns and to mobilize large numbers of people to participate in protests and boycotts. The second is the 'trust premium' enjoyed by NGOs. In many public opinion surveys, NGOs are ranked as one of the most trusted institutions in society, with this trust premium increasing over time as trust in business and government have declined. ${ }^{14}$

While the Global 1000 is increasingly under pressure to assume responsibility for its societal impact, accountability for corporate conduct is rarely asked by the shareholders of the Global 1000. Shareholders are hard to locate and be held accountable due to dispersed ownership structures and the surrendering of control of these corporations. As of 2011, the ten largest institutional investors in the world collectively held 27.1 percent of the outstanding shares, on average, across Global 1000 companies. None of these investors holds more than five percent in any of the companies and few if any would qualify as active investors that engage and affect the management of the operations of the Global 1000; rather they are passive owners that tend to view equity holdings as temporary investments. The rest of the shareholder base is widely dispersed with none of the investors holding more than one percent of the outstanding shares.

The separation of ownership and control has allowed shareholders to detach themselves from the responsibilities of a corporation to society. For example, there are hardly any cases I am aware of in which investors were heavily criticized and held accountable for the behavior of their investee. Rather the corporation itself and the senior management are held accountable for the actions of the corporation. In contrast, investors are able to trade their shares in liquid markets, and tend to do so quite often. The average holding period has fallen between one and three years in the largest stock exchanges over the last two decades. For instance, in the 1980s, the average holding period in the New York stock exchange was over 5 years, compared to 5 months in the late 2000s (OECD, 2011).

The combination of larger corporations that exert more power over society and the separation of ownership and control led to shareholders surrendering their right that the corporation should be operated for their sole interest (Berle and Means 1932). In the words of Walter Rathenau (1918), 'The depersonalization of ownership, the objectification of enterprise, and the detachment of ownership from the possessor leads to a point where the enterprise becomes transformed into an institution which resembles the State in character.' Berle and Means, while acknowledging that the stripping away of control from a shareholder's property right is essential to the creating of a liquid and freely tradeable

\footnotetext{
${ }^{14}$ See for example the surveys that underpin the trust barometer of the consulting firm Edelman.
} 
market for shares, went one step further, suggesting that giant corporations could only survive if they would serve the community's interests. "It is conceivable,--indeed it seems almost essential if the corporate system is to survive,--that the 'control' of the great corporations should develop into a purely neutral technocracy, balancing a variety of claims by various groups in the community and assigning to each a portion of the income stream on the basis of public policy rather than private cupidity." (pp. 312313). As they pointed out, the farmer is "married" to the horse, and needs the horse to thrive along with the farm and the surrounding community. A disinterested shareholder ownership of the farm does not obviate the pre-existing goals of the interdependent and thriving horse, farm, and community.

While economic activity was beginning to concentrate in a small group of companies many decades ago, as Berle and Means documented, there are still important differences that have led the large corporations of the early $21^{\text {st }}$ to assume more responsibilities compared to the large corporations of the $20^{\text {th }}$ century. First, the large corporations of today are much larger than they were even twenty or thirty years ago; on an absolute basis, their scale is multiple times what it was in the past. Second, their reach is significantly more global than it was before. As a result, their impact transcends national boundaries and makes the world more interconnected. Third, there is incredibly more information available about corporate behavior, as compared to a few decades ago. Information technologies, in particular the internet and social media, have equipped civil society with very effective means to mobilize and counteract the power of the Global 1000. Fourth, civil society has become increasingly sophisticated in collecting, analyzing, and interpreting data about corporate behavior. To match the increasing concentration of corporate power, NGO's have also experienced increasing concentration in power, with one percent of NGOs generating about 85 percent of the revenues to the non-profit sector in the US. ${ }^{15}$ Fifth, while in the early $20^{\text {th }}$ century there was a discussion of companies' social responsibilities, no mention was made of resource scarcity and planetary effects such as climate change (Eccles and Krzus, 2010). The combination of concerns about social responsibility, resource scarcity, and planetary effects further exacerbated pressure on large companies to serve the interests of society.

The implication from the discussion in this section is that the largest companies would exhibit higher environmental and social performance in terms both of managerial commitments but also observable organizational outcomes. The next section describes the increasing corporate involvement in sustainability issues and tests the relationship between firm size and environmental/social performance.

\section{Sustainability and The Corporation}

Environmental and social considerations are taking central stage in corporate agendas. The concepts of social responsibility, resource scarcity, and planetary effects culminate in the term 'sustainability.' While

\footnotetext{
${ }^{15}$ See http://www.huffingtonpost.com/ken-berger/nonprofit-effectiveness_b_2701812.html?utm_hp_ref=impact
} 
there are many definitions of sustainability, broadly speaking it represents a portfolio of environmental, social, and governance (ESG) considerations upon which company performance can be evaluated. Figure I shows the universe of sustainability issues classified in five categories by SASB. These sustainability considerations are increasingly gaining acceptance in the corporate community. For example, in the 2010 UN Global Compact - Accenture CEO study 81 percent of the respondents stated that sustainability issues are now fully embedded in the strategy and operations of their organization. ${ }^{16}$ A joint study in 2012 by the Boston Consulting Group and the MIT Sloan Management Review found that nearly 50 percent of the companies surveyed had changed their business model as a result of sustainability, a 20 percent jump over the previous year. Reflecting the rapid adoption of sustainability practices, many companies have established a new C-level executive position for sustainability officers (e.g. AT\&T, Blackstone, BT, Dow Chemical, Nestle, SAP, Siemens, Unilever, among many others).

Furthermore, the exponential growth of sustainability reporting, ${ }^{17}$ as well as integrated reporting, suggests the increasing acknowledgement that corporations should be accountable for their societal impact. For example, while only 26 firms issued a sustainability report in 1992, this number grew to 5,162 by 2010 (Eccles et al., 2011). As of 2012, more than 6,000 corporations issued sustainability reports. The exponential growth in sustainability reporting is documented in Figure II. The significant number of increase in reporting entities post 2000 can be partly attributed to the work of the GRI. GRI released an 'exposure draft' version of the Sustainability Reporting Guidelines (SRG) in 1999, the first full version of the SRG in 2000, and the second full version at the World Summit for Sustainable Development in Johannesburg in 2002, where the organization and the Guidelines were also referred to in the Plan of Implementation signed by all attending member states.

The theory articulated in the previous section suggests that size would be a first-order determinant of sustainability commitments across organizations. I test this prediction using data from Thomson Reuters ASSET4. This data has been used in a number of previous studies (Ioannou and Serafeim, 2012; Cheng, Ioannou and Serafeim, 2014). Table I uses as dependent variables the social and environmental scores assigned to each company by Thomson Reuters. The data points that comprise these scores are categorized as either "drivers" or "outcomes." Drivers "track policies that cover issues such as emission reduction, human rights, and shareholder rights" whereas outcomes "track quantitative results such as greenhouse gas emissions, personnel turnover and highest remuneration package" (Ioannou and Serafeim, 2012).

\footnotetext{
${ }^{16}$ The word sustainability usually encompasses environmental, social, and governance (ESG) issues that frame the relation between business and society.

${ }^{17}$ I describe as a sustainability report any report that includes environmental, social and/or governance firm-level data but not the financial results of a firm.
} 
Column (1) shows that 24.7 percent of the variation in the social score is explained by age of the firm (years), industry, and country fixed effects. Adding firm size as an explanatory variable to the regression increases the explanatory power by 19.5 percent to 44.2. Using environmental score as the dependent variable yields similar results. To facilitate comparison of the importance of size as an explanatory variable I also include variables that measure the risk-return profile of a firm. Specifically, I include Return-on-Equity (ROE), Market-to-Book (MTB), sales growth over the past three years, and stock return volatility as independent variables. Past research has argued that sustainability commitments are a form of luxury good and as a result can be afforded only by well-performing firms (Hong et al., 2011). Collectively, these variables add to the explanatory power of the model just 1.2 percent, raising it to 45.4 percent. Ioannou and Serafeim (2012) examine the determinants of corporate social performance, using the same dependent variables as in this paper, and find that the addition of more firm-specific variables (i.e., R\&D expenditures, financial leverage, industrial diversification, analyst coverage, ADR trading) does not increase the explanatory power of the model beyond 41 and 47 percent for social and environmental scores, respectively. Excluding firm size from the model lowers the explanatory power to 26.8 percent suggesting that the order with which the regressors enter the model does not change the results.

One implication of this analysis is that the 'corporate size' theory dominates alternative theories such as the 'luxury good' theory (Hong et al. 2011). Firm size appears to be a very important determinant of firms' social and environmental commitments. ${ }^{18}$ In contrast, firm performance appears to have been a relatively less important determinant. This is consistent with the idea that the world's largest corporations are more subject and responsive to civil society's demands.

At this point, a conversation is warranted about whether sustainability has a positive, negative, or irrelevant effect on future financial performance. If it is the case that sustainability destroys financial value, then an implication from the previous discussion is that large firms are at a competitive disadvantage compared to smaller competitors. A vicious cycle would ensue, in which large firms would be overtaken by smaller companies, with these smaller companies endangering their competitiveness as they become larger and engage in sustainability issues. From a firm competitiveness perspective, being and remaining small would be a good thing.

The evidence seems to support a positive relationship between sustainability and future financial performance (Orlitzky, Schmidt, and Rynes, 2003). Very little evidence exists to suggest that sustainability can be an impediment to corporate profitability. In contrast, evidence is emerging that under certain conditions 'sustainability pays.' For example, Eccles, Ioannou, and Serafeim (2014) show that in

\footnotetext{
${ }^{18}$ In untabulated results I include in the model, as a determinant, the natural logarithm of net income to test whether firms that have shareholders with 'deep pockets' tend to have higher environmental and social scores. I find that this variable increases the explanatory power of the model only by 0.5 percent.
} 
industries where firms extract large amounts of natural resources, compete on the basis of brand and reputation, and have customers the end consumer, firms that had integrated environmental and social policies outperform their competitors in the long-run. More generally, Serafeim (2014) shows that a firm's value creation process is dependent on six capitals: natural, human, financial, physical, intellectual, and social. The contribution of sustainability to future financial performance depends on how sustainability affects the quality of these capitals. The neutral to positive relation between sustainability and financial performance suggests that large firms are not at a competitive disadvantage relative to small firms.

\section{Opportunities for Future Research}

Because I have concentrated the discussion on the rise of the Global 1000 as an explanation for the increasing corporate commitment to sustainability, I am going to focus on opportunities for research that are relevant to the Global 1000. As a result, I will not discuss research areas that are very worthwhile but apply to smaller organizations, such as entrepreneurship, social entrepreneurship, and hybrid organizations. Moreover, I will take as given that corporations are managing and reporting on sustainability issues and as a result, I won't ask the question of whether they should be doing so. Therefore, I adopt a positive rather than a normative approach.

I start with questions about what companies actually do and how to define the materiality of the different sustainability issues for future company profitability. Having established what corporations do, I proceed to discuss how they can do it, specifically addressing issues of organizational design in terms of incentive and control systems. The next set of questions revolves around corporate reporting: how a firm communicates what it does and how it does it. Finally, I discuss the role of investors and how they can use the reported information. Figure III provides a visual description of these research topics.

\subsection{Which Sustainability Issues Does a Corporation Manage and Report On?}

A corporation affects society in a myriad of ways. As a result, the set of sustainability issues that a corporation faces can be overwhelming. These issues often include concerns around climate change, product safety, corruption, biodiversity, human rights, and political lobbying, just to name a few. Different stakeholders place more or less importance on different ESG issues and consequently lobby executives on different issues. This raises the real need for a company to narrow the set of sustainability issues and prioritize them based on their materiality.

Materiality can be thought as a measure of corporate impact on society for a specific sustainability issue. Under this line of thinking, climate change is a material issue for oil and gas firms. Human rights are a material issue for apparel manufacturers. Corruption is a material issue for extractive companies. 
Customer health and safety is a highly material issue for pharmaceutical companies. This is currently the thinking behind the Global Reporting Initiative (GRI), and guides its disclosure framework. From a societal perspective, one would want transparency on any issue that the company is having a large impact, independent of whether that impact will affect a company in the long-term. This definition of materiality poses no requirement that there is a relation between sustainability and financial performance.

Another layer can be added to the concept of materiality if it is defined as a measure of corporate impact on society for a specific sustainability issue that will eventually have an economic impact affecting the long-term financial performance of the company. This is currently the approach followed by Sustainability Accounting Standards Board (SASB), which requires evidence of economic impact in order for a sustainability issue to be deemed material. This definition of materiality imposes a requirement that an environmental or social issue can have a significant impact on a firm's long-term financial performance. An example that illustrates the difference between the two approaches is orphan drugs in the pharmaceutical industry. While rare diseases are obviously a societal issue that is of grave interest to patients, their families and many more people, there is little evidence to suggest that pharmaceutical companies that fail to invest and develop orphan drugs are impairing their long-term competitiveness.

Due to the lack of clear guidance for what is material in the realm of sustainability, some companies have attempted to determine this for themselves through stakeholder engagement. This process may be used to build a 'materiality matrix,' with one dimension being 'importance for the company' and the other being 'importance to society.' For example, telecommunications giant Telefonica has identified 'Privacy and data protection' as very important for both company and society (Eccles, Serafeim, and CanoEscoriaza, 2013). In contrast, 'Responsible marketing' is of higher importance for the company rather than society. 'Environmental protection' issues are more important for society rather than the company. 'Diversity' scores low for both society and the company. Figure IV presents Telefonica's materiality matrix for 2011 .

The data that are generated from these materiality matrices can be used to answer fundamental questions about which societal issues corporations are grappling with. First, how reasonable is the assumption of SASB that sustainability standards should be industry-specific? Is there a strong consensus among firms in the same industry about the materiality of sustainability issues? Or do country and firmspecific factors create significant disagreement? Second, how do firms respond to issues identified as important only for society but not for the company? Do they place less importance on these? Answering these questions would provide insights on which materiality definition companies subscribe to.

\subsection{How Do Executives Design Incentive and Control Systems?}


The design of incentive and control systems has a long history in management accounting. While we know a fair amount about how firms design these systems to achieve financial goals, there is almost no research on how companies design systems to achieve sustainability goals. There are some key differences between financial and sustainability goals that might give rise to important differences in system design.

First, the availability and quality of sustainability metrics is significantly lower as compared to financial metrics, increasing the noise-to-signal ratio. For example, Eccles, Ioannou, and Serafeim (2014) documented that a relatively low percentage of companies measure sustainability information and an even lower percentage obtain external assurance on the adequacy of the processes that generate the data. Moreover, performance on many sustainability issues is less controllable by the company, widening the gap between accountability and control. For example, many companies engage to improve the environmental and social performance of their supply chain partners, even though they have less control over them than they do their own operations. In addition, while monetary incentives seem to work effectively at motivating behavior to achieve financial goals, it is not clear that this would apply to sustainability goals, where motivation might be driven by intrinsic and reputational factors (Benabou and Tirole, 2006; Eccles et al. 2013). ${ }^{19}$

A first path forward for research would be to examine how sustainability metrics are used in incentive and control systems. Does the higher noise-to-signal ratio, lower controllability, and potential crowdingout of intrinsic and reputational motivation lead to less intensive use of sustainability metrics in these systems? A second set of questions revolves around the combination of financial and sustainability measures. What is the optimal combination of financial and sustainability metrics that allows a firm to achieve its objectives?

\subsection{How Does a Corporation Report its Performance and Position?}

While significant requirements already exist for financial reporting, reporting on ESG performance is a relatively new phenomenon. In 1995, Royal Dutch Shell came under fire for alleged human rights violations stemming from its operations in Nigeria. Campaigns against Shell caused some investors and the public to temporarily lose confidence in the company. As part of an effort to inform consumers and repair its reputation, Shell issued a corporate social responsibility report in 1998, becoming the first large corporation to do so.

Corporate sustainability reports and annual financial reports have typically been issued separately since companies have not customarily linked the concepts of ESG performance to financial performance.

\footnotetext{
${ }^{19}$ For an interesting read on how social norms rather than monetary incentives can be more effective a recommended article is: http://www.nytimes.com/cwire/2010/06/21/21climatewire-finding-the-weapons-of-persuasion-to-save-ene$\underline{8137 . h t m l \text { pagewanted=all. }}$.
} 
Reports containing environmental and social data vary widely in terms of structure and content due to the lack of regulatory guidelines on how to report this information. Early adopters of sustainability reporting predominately released a single issue report, usually disclosing environmental or workplace safety information. This evolved into multi-issue reports when companies began disclosing information relative to the organization's "triple bottom line," which holistically represented its economic, social, and environmental performance. This disclosure practice was most commonly referred to as corporate social responsibility (CSR) reporting or sustainability reporting.

Unlike a sustainability report that is issued separately from the annual financial report, an integrated report is a single document that presented and explained both financial and nonfinancial information in a holistic manner. Integrated reporting was developed in response to the need generated by stakeholder groups and investors for enhanced reporting that connected strategy, key performance indicators (KPI), and financial performance. A frequent argument in favor of integrated reporting is that it is an effective way of instilling 'integrated thinking' inside the firm and communicating to all stakeholders that the company is taking a holistic view of their interests.

Fundamental questions exist concerning these reporting developments. I separate these questions into three categories: determinants, reporting choices, and consequences. On determinants, what motivates a firm to disclose its ESG performance? Are the motives behind sustainability and integrated reporting similar or different? Second, how do companies choose what to report on? Does the information disclosed meet the materiality threshold, however defined? Eccles et al. (2012) report that companies in industries that will be affected by climate change (e.g., insurance, airlines, automobiles) have failed to provide climate change disclosures. Moreover, within the set of companies that report on climate change there is substantial variation on what they disclose, ranging from boilerplate disclosures to quantitative KPIs. Third, what are the consequences of sustainability and integrated reporting? Does reporting incentivize managers to improve their ESG performance? Ioannou and Serafeim (2012) studied the enactment of mandatory sustainability reporting in a sample of 58 countries, and showed that companies forced to report do in fact improve their ESG performance. Their results provide evidence that reporting can drive performance.

\subsection{What is the Role of Investors?}

Another important development has been taking place within the investment community. In many countries the socially responsible investing (SRI) movement has been gaining significant momentum, and it increasingly constitutes a non-negligible part of the broader financial system. In its early years, SRI was largely grounded and justified in terms of religious beliefs (e.g. exclusion of firms that sell weapons, tobacco, or alcohol), and it was therefore indistinguishable from ethical investing in terms of the type of 
values-driven investment screening applied. Yet as SRI developed into its modern form, it shifted away from an emphasis on ethics and towards the incorporation of ESG factors into investment decisions, thereby becoming an investment strategy (what is now termed "ESG integration") that explicitly seeks to outperform rather than simply adopt an ethical stance on behalf of its investors. Many SRI funds now use ESG data as an integral part of the investment strategy in order to improve the risk-return profile of the portfolios, ultimately uniting ESG and traditional (economic) firm valuation into a "Triple Bottom Line" (i.e. by considering all three broad dimensions of corporate performance: environmental, social, and economic). Ioannou and Serafeim (2014) note that by 2007, mutual funds that integrated ESG data in their capital allocation decisions had assets under management of more than $\$ 2.5$ and $\$ 2$ trillion dollars in the United States and Europe, respectively. Similarly, SRI funds in Canada, Japan, and Australia held $\$ 500, \$ 100$, and $\$ 64$ billion, respectively. Assets under management of socially responsible investors grew considerably: funds in the United States, United Kingdom, and Canada grew by $\$ 400, \$ 600$, and \$400 billion respectively, between 2001 and 2007 (Ioannou and Serafeim, 2013).

To formalize and further institutionalize the SRI movement, in 2003 the United Nations Environment Program Finance Initiative (UNEPFI) formed an Asset Management Working Group and commissioned 11 reports from nine mainstream research institutions to study the financial materiality of ESG issues to securities' valuation. A key finding of this initiative was that "agreement [among analysts] that environmental, social and corporate governance issues affect long-term shareholder value... [and] in some cases those effects may be profound". Two years later, in April 2006, the UN Secretary General Kofi Annan launched the Principles for Responsible Investing (UNPRI), which mainstreamed SRI, coined a new term for risk and return-driven investors ("Responsible Investors"), and refined the definition as those investors who incorporate ESG factors into their investment process. By April 2012, the UNPRI Global Network included more than 1,000 signatories with assets under management of approximately $\$ 35$ trillion. $^{20}$

The increasing momentum of the SRI movement within financial markets has also led to a proliferation of academic studies seeking to better understand the performance of SRI funds. Specifically, Sparkes \& Cowton (2004) perform a comprehensive review of this literature and find that SRI "has become an investment philosophy adopted by a growing proportion of large investment institutions" and that "this shift in SRI from margin to mainstream and the position in which institutional investors find themselves is leading to a new form of SRI shareholder pressure" (p.45, emphasis added).

During this time, mainstream investors also witnessed the emergence of sustainability indices. In 1999, for example, the Dow Jones Sustainability Indices were established as a family of indices that

\footnotetext{
${ }^{20}$ United Nations Principles for Responsible Investment, Annual Report 2012 at http://www.unpri.org/viewer/?file=wpcontent/uploads/Annualreport20121.pdf.
} 
would evaluate the sustainability performance of the largest 2,500 companies listed on the Dow Jones Global Total Stock Market Index. Several other indices followed suit, with the most prominent being the FTSE4GOOD index, Ethibel, Domini 400 Social Index, Vanguard Calvert Social Index Fund, and the Corporate Governance Quotient (CGQ). In parallel, major investment banks established units with an explicit mandate of incorporating sustainability issues into firm valuations (e.g. Goldman Sachs set up GS Sustain). These developments further reinforced the emerging belief that sustainability was linked to value creation and that financial markets could no longer regard these policies as peripheral to a corporation's strategy (Ioannou and Serafeim, 2014).

The 2000s also witnessed an increase in investor activism. The number of environmental and social issues that were the subject of shareholder resolutions in the U.S. increased significantly (Glac, 2010) and these resolutions were also increasingly more successful (Mathiasen et al., 2012). From 2008 through the first half of 2010, more than 200 institutional investors, collectively controlling a total of at least $\$ 1.5$ trillion in assets, filed or co-filed shareholder resolutions on ESG issues. Included in this group were resolutions asking firms for better disclosure and oversight of their political contributions and activities. Other recent social and environmental resolutions have addressed equal employment opportunity, climate change, human rights, and sustainability reporting. Moreover, the number of shareholder resolutions filed at U.S. companies on environmental and social issues has risen over the last decade from an annual average of 240 in 1999-2000 to more than 380 in 2007-2009 (Socially Responsible Investing Trends, 2010). The average support that shareholder advocates are receiving for shareholder resolutions on social and environmental issues is also rising (Socially Responsible Investing Trends, 2010). ${ }^{21}$ In fact, by 2012 , ESG issues constituted the majority of all shareholder proposals (Ernst \& Young, 2012). ${ }^{22}$

I categorize opportunities for research in two areas: integration and engagement. On ESG integration, there is a need for development of valuation methodologies that incorporate ESG metrics. Do ESG metrics affect cost of capital, growth or return-on-capital estimates? How do different investors practice ESG integration and what are the implications for their investment performance? On ESG engagement, how do investors choose to engage with a corporation on a specific sustainability issue? What determines the probability of success for these engagements? Dimson, Karakas, and Li (2013) documents that firms are more likely to be engaged, and engagements are more likely to be successful, if the target firm is concerned about its reputation and if it has a higher capacity to implement changes and improve its ESG performance.

\footnotetext{
${ }^{21}$ Report available at http://socialresponsibleinvest.blogspot.co.uk/2010_11_01_archive.html

${ }^{22}$ Report available for download at http://www.ey.com/US/en/Newsroom/News-releases/Environmental-and-social-topics-leadshareholder-proposal-submissions-in-2012-proxy-season
} 


\section{Conclusion}

This paper presents an alternative view of the role of the corporation in society. Specifically, the largest corporations have a role to contribute positively to society by balancing different stakeholders' interests, instead of maximizing profits. I attribute this change in the role of the corporation to the increasing concentration of economic activity and power in a few corporations which resulted in a) a few companies having a very large impact on society, b) corporations and influential actors which are easier to locate, and c) increasing separation of ownership and control. These events led to what Berle and Means (1932) predicted more than 80 years ago: both owners and 'the control' accepting public interest as the objective of the corporation.

A few interesting observations arise from this alternative formulation of the role of the corporation in society. First, it is not static, as is the goal of profit maximization. Rather, the role of the corporation in society can be a function of the broader economic, social, and political context and as a result evolves over time. Second, corporations are not a homogeneous group as it is assumed by profit maximization; not all corporations have the same role in society. For example, in this paper the largest corporations have more of their activities put to the test of public interest.

Managers engage in a range of activities. Recently, increasing corporate engagement on environmental and social goals has redefined the relation between business and society. It remains to be seen whether this trend will continue. In the meantime, research on the topics outlined in this paper is likely to increase our understanding of corporate behavior and the role of these corporations in society. 


\section{References}

Balotti, R. and Hanks, J. 1999. "Giving at the office: a reappraisal of charitable contributions by corporations.” Business Lawyer 54 (3): 956-966.

Benabou, R., \& Tirole, J. 2006. "Belief in a just world and redistributive politics." The Quarterly Journal of Economics 121 (2), 699-746.

Adolf Berle and Gardiner Means. 1932. "The Modern Corporation and Private Property." Harcourt, Brace \& World Inc.

Beiting Cheng, Ioannis Ioannou, and George Serafeim. 2014. "Corporate Social Responsibility and Access to Finance." Strategic Management Journal, 35: 1-23.

Brown, W., Helland, E., and Smith, K. 2006. Corporate philanthropic practices. Journal of Corporate Finance 12: 855-877.

Elroy Dimson, Oguzhan Karakas, and Xi Li, 2013. "Active Ownership." London Business School Working Paper.

Du, S., Bhattacharya, C. B., and Sen, S. 2007. "Reaping relational rewards from corporate social responsibility: the role of competitive positioning." International Journal of Research in Marketing 24: 224-241.

Robert G. Eccles, and Michael Krzus, 2010. "One Report: Integrated Reporting for a Sustainable Strategy." New York: John Wiley and Sons, Inc.

Robert G. Eccles and George Serafeim. November 2011. "The Role of the Board in Accelerating the Adoption of Integrated Reporting." Director Notes, 1-8.

Robert G. Eccles, Michael Krzus, and George Serafeim, 2011. "Market Interest in Nonfinancial Information." Journal of Applied Corporate Finance, Volume 23 (4), 113-127.

Robert G. Eccles, George Serafeim, and Beiting Cheng. 2011. "Foxconn Technologies." Harvard Business School Case 112-002.

Robert G. Eccles, Ioannis Ioannou, and George Serafeim. March 2012. "The Impact of Corporate Sustainability on Organizational Processes and Performance." Management Science, forthcoming.

Robert G. Eccles, Michael Krzus, Jean Rogers, and George Serafeim. 2012. "The Need for Sector Specific Materiality and Sustainability Reporting Standards." Journal of Applied Corporate Finance, Volume 24 (2), 65-71.

Robert G. Eccles, George Serafeim, and Asun Cano-Escoriaza. December 2012. "Developing the Materiality Matrix at Telefónica." Harvard Business School Case 413-088.

Robert G. Eccles and George Serafeim. 2013. "The Performance Frontier: Innovating for a Sustainable Strategy." Harvard Business Review, The Big Idea, May.

Milton Friedman, 1970. "The social responsibility of business is to increase its profits." New York Times Magazine, 13 Sept., 32 (33): 122-126. 
Robert Freeman, Harrison, J. S., Wicks, A. C., Parmar, B. L., de Colle, S. 2010. "Stakeholder theory: the state of the art." Cambridge University Press, New York, United States.

Galaskiewicz, J. 1997. “An Urban Grants Economy Revisited: Corporate Charitable Contributions in the Twin Cities, 1979-81, 1987-89.” Administrative Science Quarterly, 42(3): 445-471.

Glac, K. 2010. "The Influence of Shareholders on Corporate Social Responsibility." History of Corporate Responsibility Project Working Paper No. 2, Center for Ethical Business Cultures.

Greening, D. W. and Turban, D. B., 2000. "Corporate Social Performance as a Competitive Advantage in Attracting a Quality Workforce.” Business \& Society, 39 (3): 254-280.

Harrison Hong, Jeffrey D. Kubik and Jose Scheinkman. 2011. "Financial Constraints on Corporate Goodness." Working Paper.

Paul Healy, George Serafeim, Suraj Srinivasan, and Gwen Yu. 2013. "Market Competition, Earnings Management and Persistence in Accounting Profitability Around the World." HBS working paper.

Amy Hillman, Gerald Keim, and Douglas Schuler. 2004. "Corporate Political Activity: A Review and Research Agenda." Journal of Management, 30 (6): 837-857.

Ioannis Ioannou, and George Serafeim. 2012 "What Drives Corporate Social Performance? The Role of Nation-Level Institutions.” Journal of International Business Studies, Volume 43, 834-864.

Ioannis Ioannou, and George Serafeim. November 2012. "The Consequences of Mandatory Corporate Sustainability Reporting." Harvard Business School Working Paper.

Ioannou, Ioannis, and George Serafeim. 2014. "The Impact of Corporate Social Responsibility on Investment Recommendations: Analysts' Perceptions and Shifting Institutional Logics." Strategic Management Journal, forthcoming.

Michael Jensen, 2001. "Value Maximization, Stakeholder Theory and the Corporate Objective Function." Journal of Applied Corporate Finance (fall): 8-21.

Michael Jensen and William Meckling. 1976. Theory of the Firm: Managerial Behavior, Agency Costs and Ownership Structure. Journal of Financial Economics 3(4): 305-360.

Russell Lundholm, George Serafeim, and Gwen Yu. 2013. "FIN Around the World: The Contribution of Financing Activity to Profitability.” HBS Working paper.

Joshua Margolis, Elfenbein, H. A., and Walsh, J. P. 2013. "Does It Pay To Be Good? A Meta-Analysis and Redirection of Research on the Relationship between Corporate Social and Financial Performance." HBS Working paper.

Margolis, J. D. and Walsh, J. P. 2003. Misery loves companies: Rethinking social initiatives by business. Administrative Science Quarterly, 48(2): 268-305.

Carolyn Mathiasen, Erik Mell, and Alex Gallimore. 2012. "U.S. Proxy Season Review: Environmental and Social Issues." Institutional Shareholder Services.

Navarro, P. 1988. “Why do corporations give to charity?” Journal of Business, 61(1): 65-93. 
Lynn S. Paine. "Value Shift: Why Companies Must Merge Social and Financial Imperatives to Achieve Superior Performance.” New York: McGraw-Hill, 2004.

Charles Perrow. 2002. "Organizing America: Wealth, Power, and the Origins of Corporate Capitalism." Princeton University Press.

Jeffrey Pfeffer. 1998. "The human equation: Building profits by putting people first." Harvard Business Press.

Michael Porter, and Mark Kramer, 2011. “Creating Shared Value.” Harvard Business Review, 89 (1/2): 62-77.

OECD, 2011. "Promoting Long-term Investment by Institutional Investors: Selected Issues and Policies." OECD Discussion Note.

Marc Orlitzky, Frank L. Schmidt, and Sara L. Rynes, 2003. "Corporate Social and Financial Performance: A Meta-analysis." Organization Studies 24 (3): 403-441.

Walter Rathenau, 1918. Von kommenden Dingen, Berlin.

Charles Sellers, 1991. “The Market Revolution: Jacksonian America, 1815-1846.” New York: Oxford University Press.

US Social Investment Forum. 2010. "Socially Responsible Investing Trends.”

Sparkes, R., \& Cowton, C. J. 2004. The maturing of socially responsible investment: a review of the developing link with corporate social responsibility. Journal of Business Ethics, 52(1), 45-57.

Sen, S., Gurhan-Canli, Z. And Morwitz, V. 2001. Withholding Consumption: A Social Dilemma Perspective on Consumer Boycotts. Journal of Consumer Research, 28(3): 399-417.

Zingales, L. 2000. In Search of New Foundations. The Journal of Finance, 55(4): 1623-1653. 
Figure I

\section{Universe of Sustainability Issues}
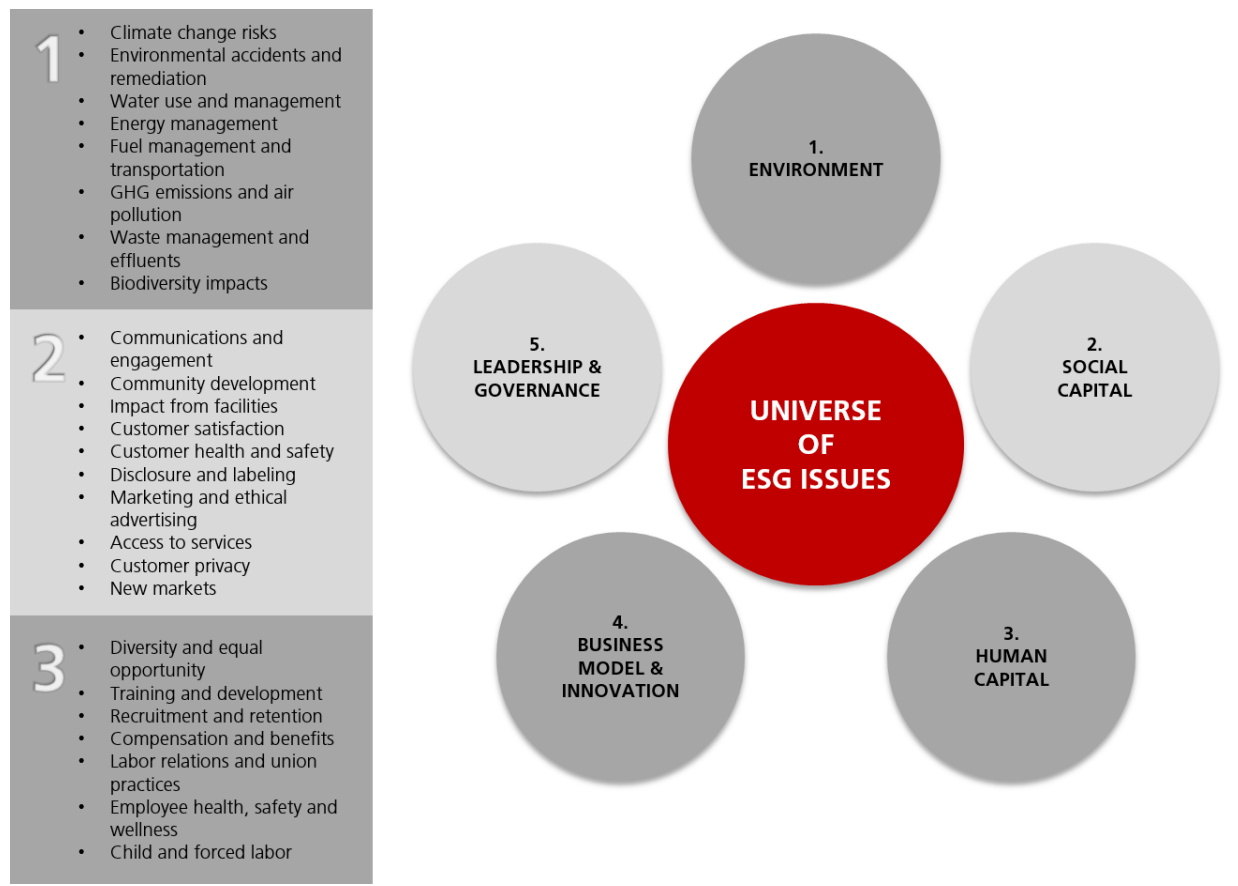

Source: http://www.sasb.org/materiality/determining-materiality/

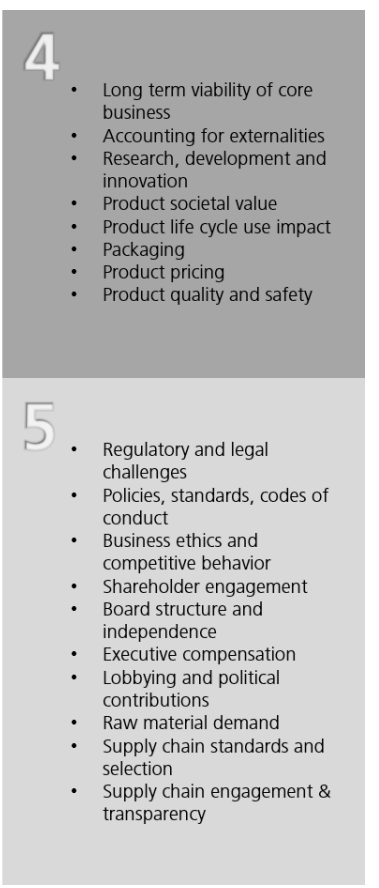


Figure II

Number of Sustainability Reports by Year

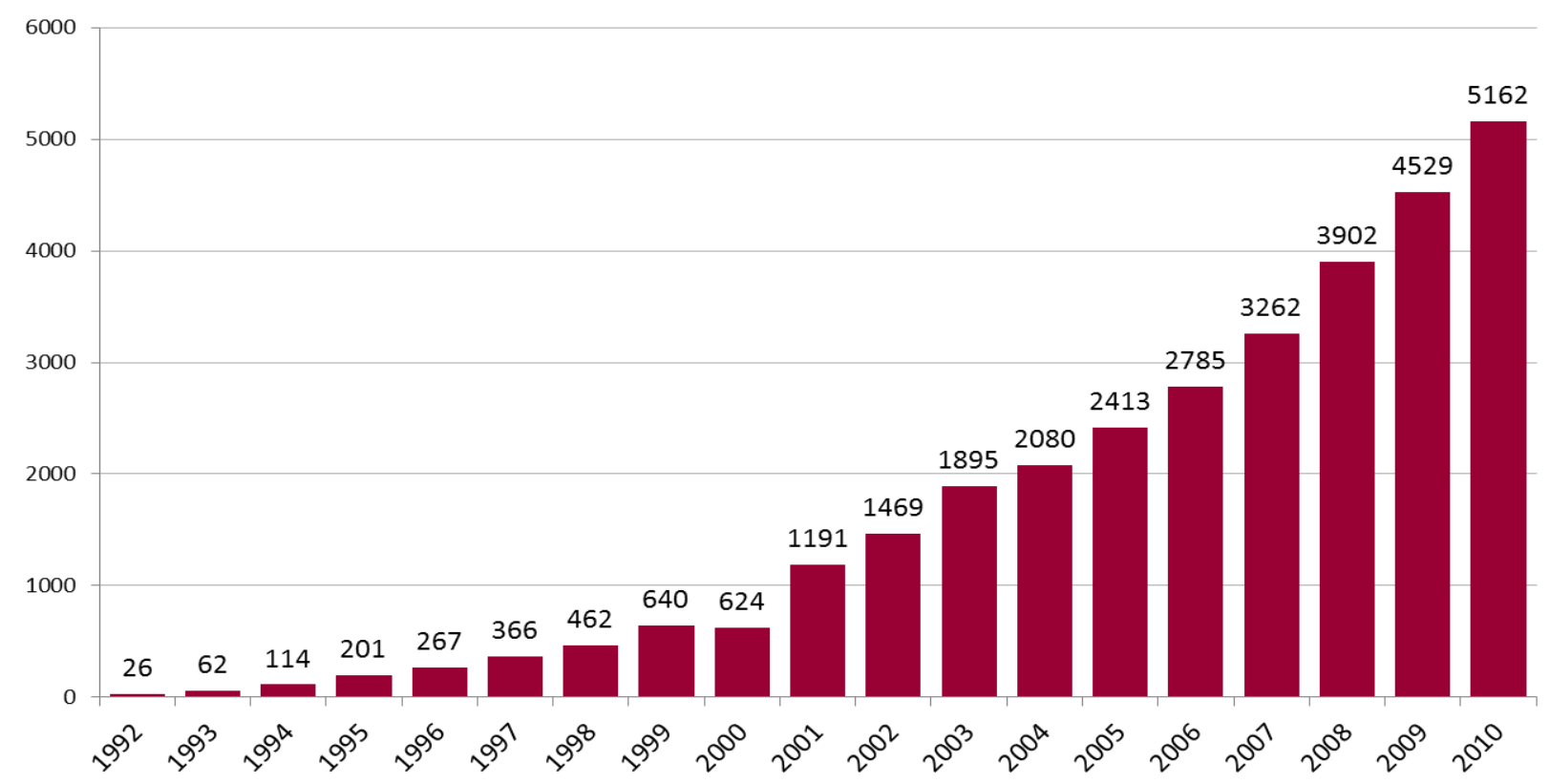

Source: Robert G. Eccles, George Serafeim, and Phillip Andrews, "Mandatory Environmental, Social, and Governance Disclosure in the European Union." Harvard Business School Case 111-120, July 2011. 
Figure III

A Framework for Future Research

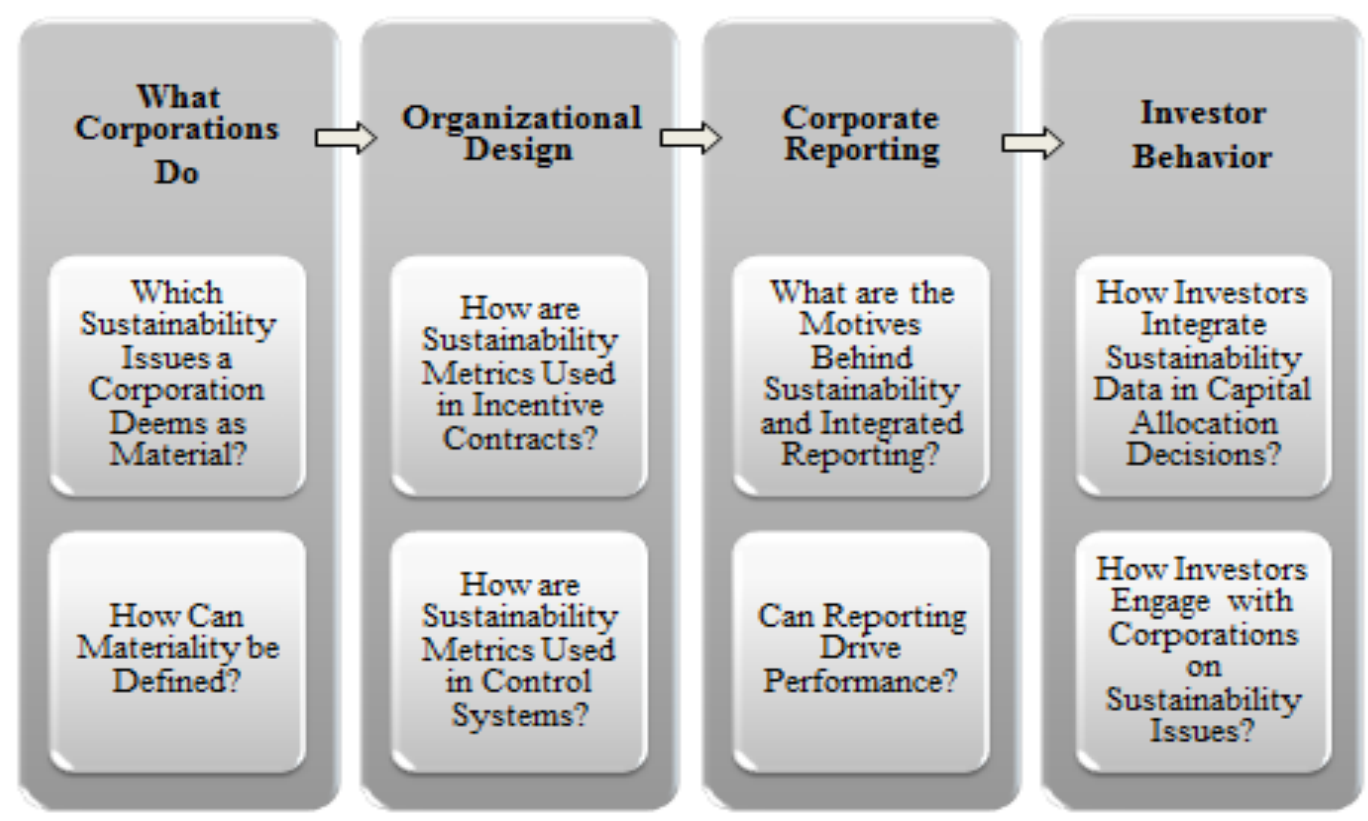


Figure IV

Telefonica's Materiality Matrix

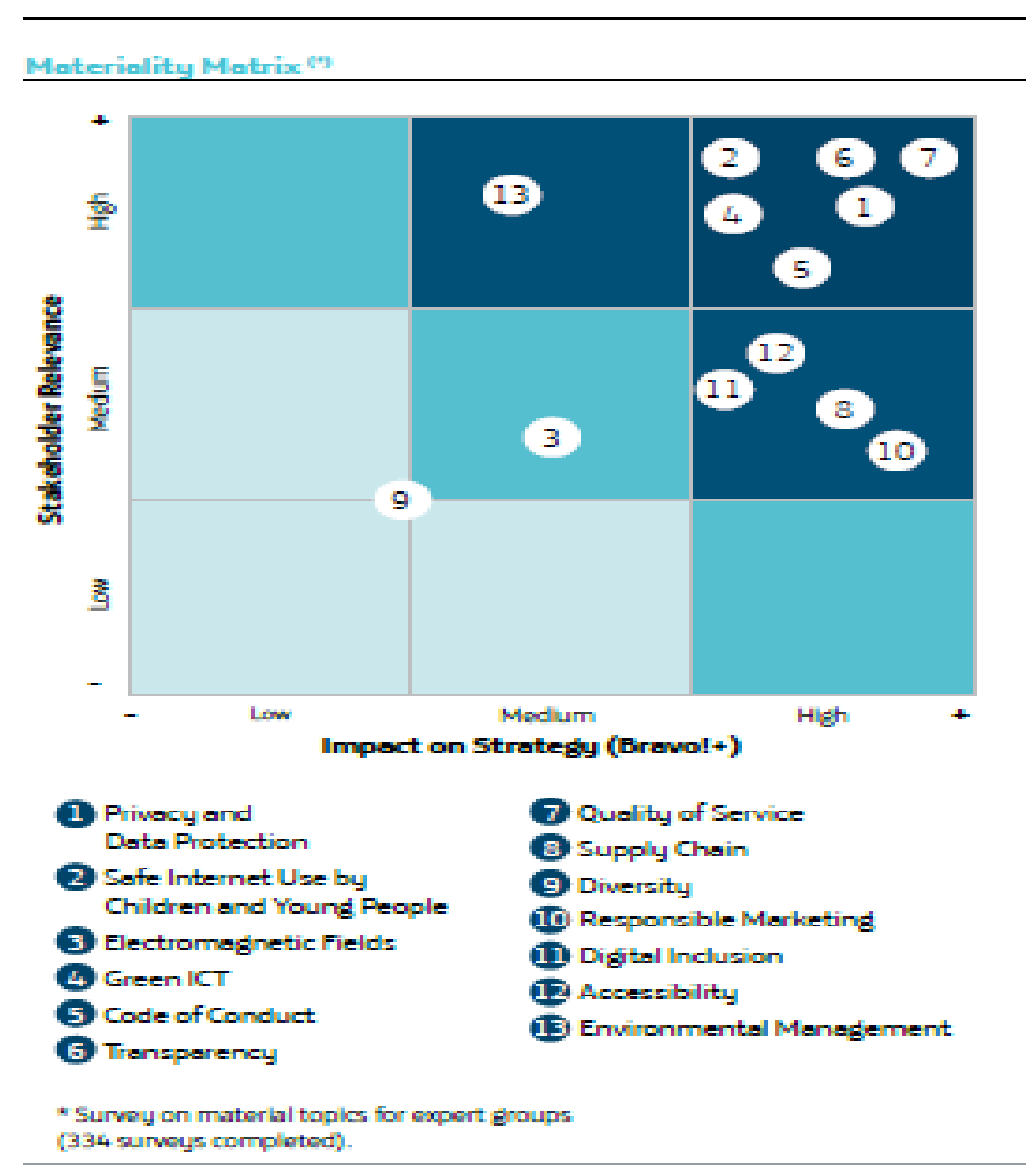

Source: Robert G. Eccles, George Serafeim, and Asun Cano-Escoriaza. December 2012. "Developing the Materiality Matrix at Telefónica.” Harvard Business School Case 413-088. 
Table I

Size as a Determinant of Social and Environmental Performance Measures

\begin{tabular}{|c|c|c|c|c|c|c|c|c|c|c|c|c|}
\hline \multirow[b]{2}{*}{ Parameter } & \multicolumn{6}{|c|}{ Social Score } & \multicolumn{6}{|c|}{ Environmental Score } \\
\hline & Estimate & $\mathrm{t}$ & Estimate & $\mathrm{t}$ & Estimate & $\mathrm{t}$ & Estimate & $\mathrm{t}$ & Estimate & $\mathrm{t}$ & Estimate & $\mathrm{t}$ \\
\hline Intercept & 60.64 & 11.59 & -33.99 & -7.87 & -32.68 & -7.58 & 54.03 & 13.57 & -37.60 & -10.01 & -37.25 & -9.54 \\
\hline Firm size & & & 11.34 & 39.73 & 11.36 & 40.53 & & & 10.98 & 37.27 & 11.02 & 37.73 \\
\hline ROE & & & & & -1.67 & -1.75 & & & & & -0.32 & -0.36 \\
\hline MTB & & & & & 1.03 & 6.77 & & & & & 0.75 & 5.33 \\
\hline Sales growth & & & & & -0.19 & -11.99 & & & & & -0.19 & -11.84 \\
\hline Volatility & & & & & -0.18 & -4.74 & & & & & -0.12 & -3.10 \\
\hline Year fixed effects & Yes & & Yes & & Yes & & Yes & & Yes & & Yes & \\
\hline Industry fixed effects & Yes & & Yes & & Yes & & Yes & & Yes & & Yes & \\
\hline Country fixed effects & Yes & & Yes & & Yes & & Yes & & Yes & & Yes & \\
\hline Adjusted R-squared & $24.7 \%$ & & $44.2 \%$ & & $45.4 \%$ & & $32.6 \%$ & & $49.6 \%$ & & $50.5 \%$ & \\
\hline $\mathrm{N}$ & 20,281 & & 20,281 & & 20,281 & & 20,281 & & 20,281 & & 20,281 & \\
\hline
\end{tabular}

Social score measures the commitment and performance of a corporation in relation to social goals. Environmental score measures the commitment and performance of a corporation in relation to environmental goals. Firm size is the natural logarithm of sales. ROE is net income over beginning of year shareholder's equity. MTB is stock price over book value of shareholder's equity per share. Sales growth is the percentage change in sales over the last three years. Volatility is the annual standard deviation of weekly stock returns. Standard errors are robust to heteroscedasticity and clustered at the firm-level. 